Karadeniz Uluslararası Bilimsel Dergi

Volume: 50, Summer-2021, p. (319-332)

ISSN: 1308-6200 DOI Number: https://doi.org/10.17498/kdeniz.947414

Research Article

Received: May 3, 2021 | Accepted: June 6, 2021

This article was checked by turnitin.

\title{
THE POLITICAL EMPHASIS OF THE GEORGIAN-OSSETIAN ETHNIC CONFRONTATION OF THE 1918-1921 AND THE COLONIALIST NATURE OF THE SOVIET RUSSIA
}

\author{
ПОЛИТИЧЕСКИЕ АСПЕКТЫ ГРУЗИНО-ОСЕТИНСКОГО \\ ПРОТИВОСТОЯНИЯ 1918-1921 ГОДОВ И КОЛОНИЗАТОРСКАЯ \\ ПРИРОДА СОВЕТСКОЙ РОССИИ
}

\section{8-1921 YILLARINDA GÜRCÜ-OSETİN MÜCADELESINIIN SIYYASİ YÖNLERI VE SOVYET RUSYA'NIN SÖMÜRGECİ DOĞASI ÜZERINE}

\section{Aleksandre MGEBRISHVILI*}

\begin{abstract}
The confrontation of the Ossetians residing in Georgian territories against the Georgian population had taken intense nature during the first decade of the past century, whereas it had become seldom, that Ossetians had raided local population and conducted violent acts, which aimed at weakening the defensive capabilities of the country, dismantling the economy, destruction of the material-cultural sites, intimidation and driving to despair of the local population.

It is thus worth noting that the Georgian side, on the one hand had hesitated to undertake critical measures, whereas, on the second hand, they had asked to impose some sanctions against the Ossetians.

The reactive wing of the strengthened Ossetian ethno-element had started the anti-state activities and had abused the trust of the Georgian Democratic republic.

The events had occurred as according the given scenario for some time, as there had been open demonstration of the aggression, they had treated the Constituent Assembly of Georgia unmannerly, had shown hostile attitude and undermined the sovereignty of the newly established republic.

The government had forced to use military operations against the rebels in order to counter their illegal actions and establish order. The operation had been overseen by Giorgi Kvinitadze and Valiko Jugeli.

It could be noted that the military actions of 1918-1920, which is widely known as Ossetian rebellions, was in fact actions of the Ossetian Bolsheviks backed by the Russian government, which had nothing to do with the peaceful Ossetian population's attitudes towards Georgia,
\end{abstract}

* ORCID: 0000-0002-4275-2417 Prof. Dr., deputy rector at Gori State Teaching University, Gori, Georgia; aleqsandre.m@gmail.com 


\section{The Political Emphasis Of The Georgian-Ossetian Ethnic Confrontation Of The ...}

as no Ossetians residing in Georgia had taken part in the mentioned actions. Every measure taken by the Bolsheviks had aimed at weakening the Georgian statehood, which would ease the way for the Russian government to widen their sphere of interest.

Despite everything, the ethnic minorities, including Ossetians, had always had a chance to develop their identity and culture. Such European values, as is tolerance and aspiration towards the freedom had always been linked to Georgia.

In general, the First Democratic republic of Georgia had established itself as the state faithful to democratic values, accountable to statehood and aspired to high civic duties.

Keywords: ethno-conflicts, occupation, territorial integrity, Georgia-Ossetian, Soviet Russia, Bolshevism.

\section{АННОТАЦИЯ}

Борьба поселившихся в Грузии осетин против грузинского народа приняла особо резкий характер в первом десятилетии прошлого века. Осетинские вооруженные отряды неоднократно предпринимали опустошительные набеги, грабежи, целью которых являлось ослабление обороноспособности страны, приведение в упадок экономики, разрушение памятников материальной культуры, устрашение и разорение населения.

Примечательно, что, если грузинская сторона, с одной стороны, воздерживалась от принятия критических мер, то, с другой стороны, высказывалось мнение о необходимости учреждения определенных санкций против осетин.

Реакционное крыло усилившегося осетинского этноэлемента вскоре подключается к антигосударственной деятельности и злоумышленно пользуется доверием Грузинской Демократической Республики. Процессы по аналогичному сценарию развиваются в течение нескольких лет. Слышны призывы к открытой агрессии, игнорируют Учредительное собрание Грузии, проявляют вражеское отношение к молодой Республике и подрывают её территориальную целостность.

С целью пресечения неправомерных действий со стороны восставших и установления в стране порядка, власти были вынуждены провести военную операцию. Операцией руководили Гиорги Квинитадзе и Валико Джугели.

Можно сказать, что вооруженные выступления 1918-1921 гг., известные как восстания осетин, в действительности представляли собой подстрекаемые российскими властями вооруженные действия сепаратистски настроенных осетинских большевиков, которые ничего общего не имели с настроем мирного осетинского населения по отношению к Грузии. Проживающий в Грузии осетинский народ не принимал участия в этих выступлениях. Все попытки большевиков были направлены на ослабление грузинского государства, что, естественно, позволяло российским властям упростить по этому направлению расширение сфер своих влияний.

Несмотря на всё это, национальные меньшинства, в том числе и осетины, всегда имели возможность национальной идентичности и культурного развития. Грузии исторически были сродни такие европейские ценности, как толерантность и стремление к свободе.

Суммируя вышесказанное, первая Грузинская Демократическая Республика утвердилась как страна, верная демократическим ценностям, стремившаяся к утверждению государственной ответственности и высокого гражданского сознания.

Ключевые слова: Етнические конфликты, оккупация, территориальная целостность, Грузия-Осетия, Советская Россия, Большевизм. 


\section{ÖZ}

Gürcistan'a yerleşen Osetinlerin Gürcülere karşı verdiği mücadeleler, özellikle geçen yüzyılın ilk on yılında keskin bir hale getirildi. Osetin silahlı kuvvetleri, amacı ülkenin savunmasını zayıflatmak, ekonomiyi düşüşe zorlamak, maddi, manevi ve kültürel değerlerini yok etmek, nüfusu korku altında tutmak için yıkıcı ve yıldırıcı baskınlar ile soygunlara defalarca girişti.

Gürcü tarafının bir yandan kritik önlemler almaktan geri adım atması, diğer yandan Osetinlere yönelik bazı yaptırımların uygulanmasının gerekli gördükleri de dikkatte değerdir. Güçlendirilmiş Osetin etnik unsurunun gerici kanadı kısa sürede devlete karşı faaliyetlere katıldı ve kötü niyette olarak yine de Gürcistan Demokratik Cumhuriyeti'nin güvenini kazand1. Bu durum birkaç yıl sürdü. Osetinlerin gerici kanadı saldırı çağrılarında bulundu ve Gürcistan Kurucu Meclisi'ni görmezden geldi, genç Cumhuriyete karşı düşmanca tavır sergileyip onun toprak bütünlüğünü zayıflatmaya kalkıştı.

İsyancıların yasadışı eylemlerini bastırmak ve ülkede düzeni sağlamak için yetkililer askeri bir operasyon düzenlemeye mecbur kaldılar. Askeri operasyon Giorgi Kvinitadze ve Valiko Cuğeli tarafından yönetildi.

Osetin isyanları olarak bilinen 1918-1921 silahlı ayaklanmaları aslında Rus yetkilileri tarafından kışkırtılmış olup ayrılıkçı Osetin Bolşeviklerin silahlı eylemleri olarak ortaya çıkmıştı ve barışçıl Osetin halkının Gürcistan'a karşı yaklaşımlarıyla hiçbir alakası yoktu. Gürcistan'da yaşayan Osetin halkı bu eylemlere katılmadı. Bolşeviklerin tüm girişimleri Gürcü devletini zayıflatmaya yönelik olup doğal olarak Rus makamlarının ilgi alanlarının da bu yönde gelişmesine yol açtı.

Tüm bunlara rağmen Gürcistan'da Osetinler de dâhil olmak üzere bütün azınlıklar her zaman ulusal kimlik ve kültürel gelişme firsatına sahip olmuşlardır. Tarihsel olarak Gürcistan’da Avrupa değerlerine benzeyen hoşgörü ve özgürlük gibi ilkeler her daim kendini muhafaza etmiştir.

Neticede, ilk Gürcistan Demokratik Cumhuriyeti, kendini demokratik değerlere sadık, devlet sorumluluğu ve yüksek yurttaşlık bilincinin oluşum ve korunmasını savunan bir ülke olarak kurulmuştur.

Anahtar kelimeler: Etnik çatışmalar, işgal, toprak bütünlüğü, Gürcistan-Osetya, Sovyet Rusya, Bolşevizm.

\section{Introduction}

As according to the findings of the Commission for the Investigation of the Status of the South Ossetian district in Georgia: "After February, during the October revolutions, the Ossetians residing in Shida Kartli, had started a movement for the national-cultural self-determination within the Georgian state.

Soon, as of the Bolshevik influence, this movement had turned into a separatist movement and had become a hearth of the instability in the Georgian democratic republic. An ethnic confrontation had occurred and kindled among Georgians and Ossetians.'(From the history of the relations between Georgian and Ossetian People, 1991:137).

The fight of the Ossetians residing in Georgia had become more intense during the first decades of the past century.

"When on the Georgian lands, we see that part of the "Intelligentsia" drives the Ossetians against Georgians is an utter ingratitude and an unjustness, which started about 20-30 years ago. The initiators of the process were the Russian officials, 


\section{The Political Emphasis Of The Georgian-Ossetian Ethnic Confrontation Of The ...}

with the leadership of Vostogorov and the educated Ossetian youth, who was schooled in Russia, as Russian granted-aided students. Vostogorov and these youth have poisoned large majority of Ossetians and this poison will stay unless Georgia will restrain its enemies and show Ossetians their faults. Where was the revolution, when part of the Ossetians "Intelligentsia" came up with a plan of the oppression of the Georgian population with Russian policy and one hundred years of slavery?"1

Fortunately, among Ossetians there had always been a part with progressive minds, which had realized the given reality and had not hesitated to express their positions. (Partnievi, 1918:N119).

Despite the fact that such actions had progressive nature, it was not enough to counter the separatist movements of Ossetians, as there had been various instances of raids, robberies, which had aimed at weakening the defensive capabilities of the country, dismantling the economy, destruction of the material-cultural sites, intimidation and driving to despair of the local population.

"This is the fourth occurrence, when Ossetians treacherously rebelled against the government of the Democratic republic of Georgia, as their rebellions occurred only, when Georgia faced grave hardships and Ossetians would stab the Georgian democracy in the back. When Denikin controlled the north Caucasus, they, with Denikin's blessing would raid Tskhinvali, while, when Bolsheviks have substituted him, then they would attack with Bolsheviks. "Nastrazhikali" and "Napristavali", Ossetians have used any means available to destroy the Georgian democratic republic, however nor Ossetians, nor the stronger enemies could destroy Georgia. It is thus worth mentioning that that Georgia forgave Ossetians the treacherous acts on three instances. When they would see the force against the, they would pretend that: we have been mistaken, and ask for forgiveness and the Georgian government would forgive them. But Ossetian betrayals would not stop. When Georgian forces would fight against the Bolshevik armies coming from Azerbaijan, they would stab the Georgian democracy once again. Georgian forces would return to Ossetia and made them pay for their betrayal in such a manner, which they would never forget”. (“Samuslimano Sakartvelo", 1920:26.VI).

\section{Research methods}

In the given article we have used not only empirical, but purely theoretical methodologies, such as: generalization, analysis, synthesis, abstraction, comparison, systematic approach. Comparative-historical method and causality analysis has been used during the research process, which on its behalf unites the mentioned theoretical methodologies.

\section{Discussion}

\footnotetext{
${ }^{1}$ This speech had been made by G. Veshapeli (In accordance to I. Ekaladze publication) on July 23, 1918 on the meeting of the Constituent Assembly of Georgia.
} 
Despite the various raids of the Ossetians, the Georgian state had abstained from taking strict measures until the very last moment. These occurrences are well described in the Georgian press.

"The unit, which was tasked to counter the Ossetian rebels, returned yesterday. They had a chance to destroy the villages located on lowlands, but they did not damage any of the villages". (Sakartvelo, 1918:31/III)

It is worth noting that the Georgia side had not only abstained from taking critical measures, rather, on the other hand expressed their opinions about setting some sanctions against the Ossetians.

"Ossetians can work and their economic potential could be used in favor of the state; however the political favoritism, which they were given by Russian over our people, is not acceptable". (Klde, 1920: N26).

In order to prevent the illegal actions of the insurgents and to establish order in the country, the government is forced to launch a military operation against the insurgents. The operation was led by Giorgi Kvinitadze and Valiko Jugheli.

As according to G. Kvinitadze, this is the third or fourth Ossetian uprising. They always ended in negotiations, however, this time the uprising was more prepared (Kvinitadze, 1998: 234). V. Jugheli deepens the process in more detail - the bad news from Tskhinvali is that it already appears to have been occupied by Ossetian rebels. We will quickly send forces there to teach the lazy a lesson. Ossetian nationalists are our evil and unspoken enemies. They always take advantage of our weaknesses and start a rebellion against us. A few years ago, their revolts made it easier for the Turks to take Batumi. Last year they helped Denikin, and now with the Bolsheviks, they are fighting together. We are already tired of these endless uprisings ... (Jugeli, 1920: 227).

The mobilization of military units is planned for June 10 in Gori. The composition was determined by two mountain batteries, eight battalions and a cavalry regiment. General Koniashvili was appointed the leader of the detachment.

Newspaper "Ertoba"wrote: "The strict measures that our republic is forced to take to curb the third insurgent region of Ossetia will be a purely defensive act against the enemy invading from the north, it will be a fight against aggressors and thugs to protect the locals, to save the republic and democracy." ("Ertoba", 1920: N 130)

In the second half of June 1920, the newspaper "Sakartvelos Respublika" reported to the readers about the new information spread by the General Staff (June 21) that after the capture of Roki Pass all the villages were cleared and the territory of Georgia was liberated from the insurgents ("Sakartvelos Respublika", 1920: \# 138).

As according to M. Guntsadze, "in fact, this ended the whole operation, which envisaged the liberation of this area of Shida Kartli from the insurgents. This was one of the bloodiest wars in the history of democratic Georgia ..." (Guntsadze, 2013-2014: 53).

It can be noted that the above-mentioned armed demonstrations, known as the Ossetian uprisings, were in fact separatist-motivated armed demonstrations of 


\section{The Political Emphasis Of The Georgian-Ossetian Ethnic Confrontation Of The ...}

the separatist Ossetian Bolsheviks backed by the Russian authorities, which had nothing to do with the peaceful Ossetian population attitudes towards Georgia. Ossetian people residing in Georgia did not take part in these actions. All attempts by the Bolsheviks were aimed at weakening the Georgian state, which, naturally, would make it easier for the Russian government to expand its spheres of influence in this direction. As the Military Minister of Georgia Grigol Lortkipanidze wrote: "Russia invading through the Roki Pass, staged an" Ossetian uprising "(Lortkipanidze, 1995: 152).

As we have already mentioned, shortly before the Soviet occupation of Georgia, the first government of the independent Democratic Republic of Georgia, despite numerous warnings, was forced to restore order in the Tskhinvali region. After the successful completion of the brief hostilities, the fact of the visit of the Minister of Internal Affairs to the region, naturally, would not be left out of the attention of the newspaper "Ertoba". The August 1 issue informed the readers about this event: "The Minister ${ }^{2}$ left for Tskhinvali the same day. There he was met by representatives of the local community, the Guard, the Army and others. The members of the Coast Guard were lined up on the main street of Tskhinvali. The Minister greeted the soldiers on behalf of the Government of the Republic and wished them courage and devotion in the fight against the enemies for the benefit of the Republic" (Ertoba, 1920: \# 172).

It is noteworthy in this text that the primary warning and ordinance of the Minister is aimed at preventing all forms of violence. Its purpose is to make citizens of all nationalities and beliefs feel protected. "Our republic is a democratic republic because it equally protects the interests of all its citizens, regardless of nationality and religion. But at the same time it will punish equally all those, who wish and desire to crush in the blood, the republic created by the working people, through revolt and civil war"'(Ertoba, 1920: N 172).

In general, the first democratic republic of Georgia has established itself as a country committed to democratic values, striving for state responsibility and high civic consciousness. Various social institutions had been established. Although the weak independent economic system has complicated the situation, protests have become frequent, but still, especially in the peripheries, the establishment of various political institutions is striking, that had laid the foundations for collective unions of workers.

"Unions, both institutionally and ideologically, have played an important role in public life, which has contributed to the formation of specific directions of state policy, a certain practice of putting the demands of the people on the public agenda" (Life of Georgian Regions 1918-1921, 2018: 171).

\footnotetext{
${ }^{2}$ The fist minister of Internal Affairs, N. Ramishvili is meant in this case. Apart from him, on July 28, 1920 the members of the delegation to Gori and Tskhinvali had been Direcotr of the Chancellery, S. Gelashvili and the Inspector of the Administration of the Republic, I. Kartsivadze.
} 
Of course, the political tactics of these unions were not always monotonous and often it had become radical.

Foreign Minister Evgeni Gegechkori ${ }^{3}$ discusses the political course taken by the Democratic Republic of Georgia: We went through heavy and fatal waves. Despite the fateful situation, we have not been betrayed for our goals, for democracy, and we can confidently say that we serve the people. We have made enough sacrifices for this, many people have been sacrificed for it, we have been on the right path, we have set the goal of achieving the best results in the name of democracy "(Ertoba, 1920: \# 32).

The speaker discusses in detail the external and domestic factors of the country, the difficult situation created. The main goal of the government, which is to gather strength in this common difficult times and to avoid suffering for the people. To produce maximum goodwill and good neighborly policies with neighboring peoples, to strengthen solidarity between people, and in this way to achieve a normal state of affairs.

"In this age of general turmoil, we have come to this day. This clearly testifies to the right movement of our people, its steadfastness, and our self-sacrifice. Our goal Democracy - is the means to the ultimate victory of democracy, I believe that whatever obstacles we face we will overcome with your help. We will be victorious in this great battle together with international democracy"(Ertoba, 1920: \# 32).

It is true that the struggle for the establishment of democratic values is the main task of the government, but the issue of Ossetian arbitrariness is a very hindering factor on the way to this goal. Throughout the existence of the First Democratic Republic, the periodical press was covered with a red line with materials about Ossetian armed demonstrations, assaults, then the laying down of their weapons, calls for peace, friendly coexistence, then protests again, and so on.

Aleksandre Machabeli's ${ }^{4}$ opinion on the settlement of Ossetians in the Tskhinvali region is interesting in this regard, as he notes, these places "were inhabited by Georgians only half a century ago, but due to the current situation this lands were emptied of Georgians, who came to Gori and Ossetians were settled in their settlements for a total of sixty-eighty years, which was facilitated by the Russian government" (Machabeli, 1921: №6).

The reactionary wing of the growing Ossetian ethno-element soon became involved in anti-state activities and abused the trust of the Democratic Republic of Georgia. A clear proof of this is the fact that the Ossetian National Council, which has a dubious reputation, is in charge of handing over weapons to the rebels who had

${ }^{3}$ E. Gegetchkori had acted as the head of the South Caucasian government (Sejm) from February 10, 1918, while from March 21, 1919 as the Minister of Foreign Affairs and from 1921 in combinability as the Minister of Justice.

4 Aleksandre Machabeli, Son of Davit (1874-1937) - resident of village Kurta, near Tskhinvali, statesman, folklorist. In 1937 he had been sentenced to be shot being accused of espionage. 


\section{The Political Emphasis Of The Georgian-Ossetian Ethnic Confrontation Of The ...}

been intimidated after the attack on Tskhinvali in 1918. This fact was immediately protested by the newspaper "Klde": "Ossetians, in the republic have a special privilege (probably having a function of a bridge to Russia) ... Their National Council is effectively endowed with autonomy by our government, even in matters such as laying down arms ... This, we call "Foreign Policy" of the international democracy! ... "(Klde, 1918: 4).

Prior to these events, according to the information of the same newspaper "Klde", there were villages in Kartli that do not recognize the Georgian government, gather forces, sell crops to buy weapons and do not hide their intention not to obey the central government, fight against Georgia and wait for the start of hostilities.

The same exact thing had happened and the government was soon forced to show strength to these villages and make them lay down arms, to those deceived by provocations.

Events unfold in a similar scenario next year. The voice of open aggression is heard again, the Constituent Assembly of Georgia is still treated harshly; they show hostility and undermine the territorial integrity of the young republic.

"Now it has become a spring for the Ossetians in twofold and they have two opportunities to solve their crafty affairs. The Ossetians residing in the gorge are still preparing for a new uprisings this summer and do not even hide the hope that they will win now and pay our government and the Georgian people in retaliation for last year's defeat. Last year, if the Ossetians hoped for the Bolsheviks, today they want to use Denikin's army, and surprisingly, they will not give up on this attempt. So the agreed protests of the Ossetians is without a doubt happening and this is said even by those who stand close to these actions" (Sakartvelo, 1919: №114).

Of course, the preliminary assumption was again justified; the Republic of Georgia still needed to restore order by force. The plan of revenge failed, most of the rebels fled to the mountains of Kartli and North Ossetia. Thus we would like to bring one of the 1919 references of the Ministry of Internal Affairs of the country, which reflects the facts of the fight against the armed criminal groups located in the mountains.

"The Minister of Internal Affairs received the following telegram from Tskhinvali from the Chairman of the South Ossetian Congress Paliashvili:" According to the resolution of the North Ossetian Congress and personal negotiations, I sent a mixed detachment to South Ossetia to fight the anarchy of rebels and volunteers. Six members of criminal gangs have been presented to the National Council in recent days. Arrest continues" (Sakartvelos Republika, 1919: №27).

As it is known, the anti-state events envisaged by the above-mentioned Ossetian scenario had been repeated for the third time in the following 1920.

It should be noted that such actions have caused the greatest damage to the economic development of the country in general and the region in particular, greatly aggravating the social situation. It is true that peace was restored through the efforts of the government, but the locals were not allowed to return to the rhythm of normal life until the end. The mountainous parts of the Tskhinvali region have become a 
refuge for fighters against the Republic of Georgia. Naturally, in turn, this circumstance led to the emergence of a severe criminal situation. The people of the mountainous areas did not take part in the life of the country at all; the complete incompetence of the Ossetian National Council was compounded by numerous raids, robberies and murders, attacks on civilians in the lowlands, which created a sense of terror among the locals.

"After the departure of part of the People's Guard from Tskhinvali, criminal acts have significantly increased. The National Council of the South Ossetians turned out to be helpless in resolving the issue of disarmament and other issues, as it turned out, with its decrees it greatly hindered the work of the district administration "(Klde, 1918: №12).

The problem of laying down arms for the criminal elements is addressed extensively in various central periodicals, and the reader is instantly informed of each new fact. Here is another note on the information received from the Ministry of Internal Affairs of the Republic: "The Ministry of Internal Affairs is being informed from Tskhinvali that the disarmament of mountainous Ossetia continues. Most of the residents of the Java district have already handed in their weapons, while others continue to do so. New wave of soldiers have already been sent to Gori. The criminal elements, who were causing trouble and protesting in Ossetia, are now hiding in forests "(Sakartvelos Respublika, 1919: №290).

After all, national minorities, including Ossetians, have always had the opportunity for national self-determination and cultural development. European values such as tolerance and striving for freedom have historically been ingrained in Georgia. According to the collection of legal acts of the Democratic Republic of Georgia, national minorities have been allocated 26 seats in the National Council formed since 1917, including Armenians - 10, Tatars - 4, Abkhazians - 3, Ossetians - 2, Georgian Israelis - 2, Russians - 2, Jews - 1, the Greeks -1 and the Germans - 1 . (Collection of Legal Acts of the Democratic Republic of Georgia (1918-1921), 1990: $62)$.

Apart from the repeatedly mentioned Ossetian National Council, political unions formed on other ethnic grounds functioned freely, completely without problems. Ethnic diversity was evident among officials in the central state or in local structures. Representatives of other ethnic groups, both civilian and military, were appointed to high positions without any restrictions.

According to Prof. O. Janelidze, the Georgian political elites were committed to democratic principles. The democratic aspirations of the main political spectrum (Social-Democratic Workers' Party (Mensheviks), Social-Federalist Party, National-Democratic Party, Socialist-Revolutionary Party) made it possible to establish a political pluralism-multiparty political system in the country. In addition to the ruling power, the opposition also played an important role in the political process of the state. The political opposition was mainly represented in the parliament (first in the National Council since March 1919 - in the constituent assembly) and was of a local nature. The government and the opposition, despite their ideological differences and diversity, had a common strategic goal, but differed 


\section{The Political Emphasis Of The Georgian-Ossetian Ethnic Confrontation Of The ...}

in the ways, means and methods of achieving it. The exception was the Bolshevik organizations as they did not recognize the Democratic Republic of Georgia. They opposed not the sovereignty of the country; rather they feared the sovereign Georgian state and desired its overthrow. This "fifth column" of the Kremlin was not considered opposition, but in May 1920, under a peace treaty with Soviet Russia, the legal activities of the Bolsheviks were allowed (Janelidze, 2018: 110-111).

In addition to the entry in the Act of Independence of Georgia of May 26, 1918 , on the readiness to create a free development arena for all ethnic minorities residing on the territory of Georgia, the issue of the rights of national minorities was addressed in Chapter Fourteen of the Constitution of the Democratic Republic. Materials in the press of the period show that leaders of various ranks often had to walk from village to village, especially in small settlements in Georgia, to explain in a language they could understand the country's democratic course and day-to-day struggles for freedom.

We present one of such gathering, which was held on December 17, 1919 at the initiative of the field headquarters. The agenda of the meeting includes such issues as: the importance of Georgia's independence, the main vectors of the country's foreign policy, the longing for and solidarity between nations. The attending community consisted of: residents of Java, Roki, Kemulti, Vaneli, Kornisi, Tsunari, Ortavi and Beloti. Al. Zasokhov's candidacy had been named as the head of the meeting. The head of the squad, G. Khimshiashvili also made a speech "He briefly explained to the congress the purpose of the Georgian troop's expedition. $\mathrm{He}$ noted that the people appreciated the needs of the government and expressed the hope that from now on, there would be no misunderstandings.

Then the head of the administrative department of the union V. Kartsivadze spoke, who explained to the people the importance of decency in a democratic republic and what people can do for it.

After Kartsivadze's speech, B. Iluridze and I. Jioshvili spoke on behalf of the field headquarters. They called on the Congress to stand by Georgia's democracy. Giorgi Gagloev, a member of the Constituent Assembly, made a report on the work of the Constituent Assembly in Ossetian. The reporter mentioned the main reasons for Georgia's independence and the significance of the historical act of May 26." (Ertoba, 1920: N3).

C. Gagloev diligently explained to the people that any anarchy is a betrayal along with a crime. He referred to the composition of the Georgian Parliament and explained to the people that it included representatives of small nations residing in Georgia, including the Ossetian National Council. He also introduced the people the work of the Constituent Assembly on agriculture, forestry, education, taxation and judicial policy, and more. The report made a great impression. The following resolution was adopted at the end: The numerous congresses of mountainous Ossetia, in the form of representatives of all the villages, recognize that they will fight together with the democracy of Georgia to defend the independence and freedom of Georgia. Expresses full confidence in the Constituent Assembly of Georgia, in the 
government they trust, and promises active assistance in the struggle to achieve their goals (Ertoba, 1920: N3).

A similar meeting was held on December 18, 1919 in Tskhinvali. Before the meeting in Tskhinvali, a funeral anthem was performed, commemorating the heroically killed persons in the Georgia-Armenian war: S. Maisuradze, M. Kuchukhidze, Sh. Kasradze (from Tskhinvali) and other warriors. On behalf of the Women's Organization, Ol. Sologashvili ${ }^{5}$ and also B. Iluridze addressed the public. I. Gabunia, on behalf of Gori District Headquarters, G. Gagloev, on behalf of the Social Democratic Faction (Unity, 1920: N3).

Activities like these were of great importance in terms of awakening the people and awakening the patriotic charge. Raising public awareness has become an integral part of the government's day-to-day operations by providing the society with a personal account. During a special congress of the Guard in Gori on December 20, 1919, G. Kasradze from Tskhinvali had pointed out the need to work among the people: "A dangerous situation has passed. The impudent villages have collapsed and are now leading a peaceful life. The Guard was formed and the headquarters was established. Here - there are weapons left. The general disarmament left a good impression. The great bandits have fled and now it is of utmost importance to work with the people. (Ertoba, 1920: N3).

From the very beginning of the existence of the Democratic Republic of Georgia, national minorities have been given the opportunity for free cultural, economic and social development. The Republic remained fully committed to the postulates declared from the beginning to the small minority groups residing in its territory. As of the policy towards the Ossetians, we mean the consent given by the government to the opening of Ossetian higher primary schools in Tskhinvali and Java, as well as the mandates allocated to the National Council, the three mandates defined by the Social Democratic Party list for Ossetian citizens, in this case G. Gagloevi, A. Parnievi, K. Panievi et al. Among the alternative ways of solving the problem, the government's approach to the Ossetian issue has undoubtedly been a progressive and justified way.

In the opinion of the authorities, they were willing to listen and discuss the legitimate demands of all nations. "As for the essentials of any nation's needs, we say: 'If this nation is mature enough to take care of its own affairs, unless it incurs inappropriate expenses for the state, we will never go against the needs of such a nation."

So why are we against the the Ossetian National Council? Of course, not because the Ossetians demand autonomy, on the contrary, we declare that the Ossetians do not demand any autonomy and the people, as such, have never rallied against the Democratic Republic of Georgia. Ossetians are not even asked about the scoundrels, who are in the South Ossetian National Council. They supported the Tskhinvali uprising. Then, when anarchy increased, they formed the National Council, which made a name for itself with a variety of dark and criminal activities.

${ }^{5}$ Anna Sogolashvili (daughter of Ilia Sogolashvili), a member of the National Assembly. 


\section{The Political Emphasis Of The Georgian-Ossetian Ethnic Confrontation Of The ...}

According to this activity, we can say with certainty: the Ossetian National Council is not a carrier of a national idea; it is a counter-revolutionary organization led by "officials" of the old establishment and former "'"Strazhniks (trainees)". This organization is clearly on its way to Denikin's path" (Ertoba, 1919: N107).

As you know, it is difficult to find a precedent when any country is allowed to create any type of state formation for a small nation living in its territory (if they have a homeland elsewhere).

It is thus vivid, that the Democratic Republic of Georgia could not allow an exception. Unfortunately, the deterioration of the situation in this case was greatly facilitated by the large number of soldiers returning to their villages from the front line in late 1917. The situation was uncontrollable by the arbitrariness of the armed forces organized by them, who diligently looted and assaulted the local population. The factor of Ossetians migrating from the North Caucasus and the third force, that is, in this case, Russia, remained a serious problem.

As for the Ossetians residing in Shida Kartli, as according to Prof. O. Janelidze, they were not driven by hatred of the Georgian people in general, but by fear of the state. Georgian state was a novelty for them. At the same time, they threatened to restrict the usual way of life of the Ossetians and to put them in a certain framework. The armed Ossetians were particularly hostile to the local government, which was establishing order on behalf of the state instead of anarchy, calling on illegal combat units to lay down their arms and disband. Ossetians did not agree to disarmament, disobeyed government structures and resisted (Janelidze, 2018: 183).

Unfortunately, Georgian Bolsheviks had also been actively involved in the Ossetian armed demonstrations in 1918-1921.

V. Jugheli had called on the Constituent Assembly ${ }^{6}$ to fight against the spread and contagion of Bolshevism. He pointed out that if before there was turmoil and arrogance in every human being, now the true face of the Bolsheviks is clearly visible and this arrogance will no longer have a place among us. We may still want to stir up trouble inside, but the more severely we suppress the speech of traitors and bandits. Everyone should know that the country is facing presence or absence. We will die and we will not give one step to the enemy. Jugheli adds that he is not against good neighborly relations and peaceful negotiations. However, he does not rule out the need for preparations for hostilities in order to "give a deadly blow to the red imperialism if it dares to try to destroy our freedom" ("Samuslimano Sakartvelo", 1920: \# 356).

Despite the given reality, Georgia's strategy has always been loyal, compromising and conciliatory. We will attest one publication of newspaper "Sakartvelo" to highlight what has been said. After the tragic events of 1920, Ossetian armed forces and the population in the North Caucasus highlands "robbed their fellow Ossetians of their goods, property, wives and daughters, and Ossetians in such conditions missed death here in Georgia." ("Sakartvelo", 1921: \# 5)

${ }^{6}$ The mentioned meeting of the Constituent Assembly of Georgia had taken place on April 30, 1920. 
As soon as such information was spread, the central government allowed the displaced civilians to return to their homes. After that, the Ossetians "had been motivated and came to Tskhinvali to trade". The story of the permission to stand here was heard by the Ossetians beyond the mountain and they will head to the abandoned homeland en masse through the passage of Zekari and Roki" "'Sakartvelo", 1921, \# $5)$.

The civilians soon returned to their homes. They continued to live as ordinary citizens without any restrictions. The authorities believed that the problem here existed only in separatist militias and not in the Ossetian people in general.

"The will of the nationalists is completely different and the spirit of the masses is different ... The working people of Ossetia, the peasantry and the workers cannot be held accountable for the actions of the Ossetian nationalists. Ossetia cannot think that it will be happy with enmity with Georgia. Ossetia does not have its own culture, it does not have a common territory - so it is impossible to think that Ossetia is an independent state" (Ertoba, 1918: \# 164).

Newspaper "Ertoba" indicates that the conscious and self-aware part of the Ossetian people has a great duty at hand. They should be well aware of the dangers that Ossetia may face if the Democratic Republic of Georgia is defeated. It is the duty of the conscious part of this nation to explain to the Ossetian democracy the dangers posed to them by the criminal acts of others, that the Ossetian armed demonstrations are dangerous for Georgia, but it is even more dangerous for the Ossetians themselves.

\section{Conclusion}

In the current paper, we tried to showcase the confrontation of the Ossetians residing in Georgian territories against the Georgian population had taken intense nature during the first decade of the past century, whereas it had become seldom, that Ossetians had raided local population and conducted violent acts, which aimed at weakening the defensive capabilities of the country, dismantling the economy, destruction of the material-cultural sites, intimidation and driving to despair of the local population.

It is thus worth noting that the Georgian side, on the one hand had hesitated to undertake critical measures, whereas, on the second hand, they had asked to impose some sanctions against the Ossetians.

The reactive wing of the strengthened Ossetian ethno-element had started the anti-state activities and had abused the trust of the Georgian Democratic republic.

The events had occurred as according the given scenario for some time, as there had been open demonstration of the aggression, they had treated the Constituent Assembly of Georgia unmannerly, had shown hostile attitude and undermined the sovereignty of the newly established republic.

\section{Bibliography}

Guntsadze, M., (2013-2014), 1920 Ossetian Uprising in Shida Kartli According to Georgian Press Materials, Georgian Source Studies, XV-XVI, Tbilisi. 
Kvinitadze, G., (1998), Memoirs, Vol. I, Tbilisi.

Lortkipanidze, G., (1995), Thoughts on Georgia, Tbilisi.

Life of the regions of Georgia in 1918-1921 (Civic Activism Research Center), (2018), Tbilisi.

From the History of the Relations between the Georgian and Ossetian Peoples (Conclusion of the Commission for the Study of the Status of the South Ossetian Region), (1991), Tbilisi.

Janelidze, O., (2018), Essays on the History of the Democratic Republic of Georgia, Tbilisi.

Jugeli, V., (1920), Heavy burden, Tiflis.

Ertoba, Newspaper., (1918), \# 164, Tbilisi.

Ertoba, newspaper. (1919), N107, Tbilisi.

Ertoba, Newspaper. (1920), N3, Tbilisi.

Ertoba, Newspaper., (1920), \# 32, Tbilisi.

Ertoba, Newspaper., (1920), \# 130, Tbilisi.

Ertoba, Newspaper., (1920), \# 172, Tbilisi.

Klde, Newspaper., (1918), №3, Tbilisi.

Klde, Newspaper., (1918), №12, Tbilisi.

Klde, Newspaper., (1920), 14 / VI, №26, Tbilisi.

Machabeli, A., (1921), Tskhinvali, Georgia, newspaper., №6, Tbilisi.

Parnievi, A., (1918), Ossetians in Georgia, Ertoba, newspaper, №119.

"Samuslimano Sakartvelo" (Muslim Georgia), newspaper. (1920), 26 / VI, Batumi.

"Samuslimano Sakartvelo" (Muslim Georgia), newspaper. (1920), N 356, Batumi.

"Sakartvelo" (Georgia), Newspaper., (1918), 31 / III, Tbilisi.

"Sakartvelo" (Georgia), Newspaper., (1919), №114, Tbilisi.

"Sakartvelo" (Georgia), Newspaper., (1921), \# 5, Tbilisi.

"Sakartvelos Respublika" (Republic of Georgia), newspaper. (1919), №27, Tbilisi.

"Sakartvelos Respublika" (Republic of Georgia), newspaper. (1919), №290, Tbilisi.

"Sakartvelos Respublika" (Republic of Georgia), newspaper. (1920), \# 138, Tbilisi.

Collection of legal acts of the Georgian democratic republic (1918-1921), (1990), Tbilisi. 